\title{
Cyber Media Policy on Diversity: Carefulness and Neutrality for the Sustainability of the News Coverage
}

\author{
Eko Harry Susanto ${ }^{1 *}$ Ahmad Junaidi ${ }^{1}$ Farid Rusdi ${ }^{1}$ Dennis Akbar Satrio ${ }^{2}$ \\ ${ }^{1}$ Faculty of Communication, Universitas Tarumanagara, Jakarta, Indonesia \\ ${ }^{2}$ Department of Public Administration, College of Administrative Sciences - YPIAMI, Jakarta 14350, Indonesia \\ *Corresponding author. Email: ekos@fikom.untar.ac.id
}

\begin{abstract}
Freedom of communication provides opportunities for cyber media on the news coverage of diversity to public. The government laws and regulations as well as news ethics become references when carrying out urban functions. However, media owners can impose additional limits on journalists for the continuity of cyber media operations. In accordance with the social function of cyber media in providing information to the public, the news coverage of cyber media must continue to carry out the diversity that society expects. Therefore, there are two aspects that the cyber media must implement. Firstly, it bases on media policies as well as media laws and regulations. Secondly, the cyber media carries out the news coverage of diversity precisely and carefully. The research purpose aims to describe the news coverage policy of cyber media and the news coverage of diversity in the regional level. It uses qualitative research methods. Data collection comes from informants who were determined purposively. The research results show that cyber media policy in the news coverage of diversity for the sake of cyber media operational sustainability, and the news coverage of diversity prioritizes the neutrality and independence of the news coverage.
\end{abstract}

Keywords: cyber media, media policy, news coverage of diversity, neutrality of news coverage

\section{INTRODUCTION}

In the era of freedom communication in Indonesia, cyber media is growing fast. It is able to position itself as a source of information that public can use as a reference as well. Cyber media develops because the flexibility in multiple activities in one opportunity work using communication technology. It produces online journalism in the news coverage that get support from a flexible and fast internet. [1]

Based on data from the Indonesian Cyber Media Association (AMSI), the number of cyber media throughout Indonesia has reached 2700 online media or cyber media. [2]. These includes cyber media in the region level and those in the capital city that have operational offices in the region level.

The existing laws and regulations provide guarantee to the freedom of communication in seeking, obtaining, and utilizing information. However, there are any restrictions that the public and cyber media that use information must obey. Moreover, the cyber media internally has restrictions on the news coverage of diversity in Indonesia. In this context, the cyber media pays attention to the condition of society as media audience.

The news coverage of diversity in cyber media has references as issued in the Indonesian Press Council. Moreover, cyber media journalists also adhere the code of ethics issued by the Indonesian Journalists Association
(PWI), the Indonesian Association of Indonesian Journalists (AJI), and the Journalists Association for Diversity (SEJUK) as organizations of journalists from various mainstream media, human rights activists (HAM), the interfaith dialogue and writers on diversity.

Considering that Indonesia has various ethnic groups, cultures and religions, the news coverage in cyber is a factor that must become serious concern. Because mistakes in the news coverage will trigger potential conflicts. Therefore, the cyber media policy in the news coverage of diversity is very careful. According to Robbin Mansel, media policy is an attempt from the media to comply with government laws and regulations, public opinion, and the interests of the media industry in carrying out its news coverage function [3]. Careful action has been taken by cyber media in West Java, East Java, West Kalimantan, and South Sulawesi.

In terms of media policy, journalists must carry out the functions of cyber media, i.e. providing information to people in need. At the ideal level, public needs information, and it is not not fake news with unclear sources. This does not neglect sensitivity issue to the prevailing values in society as a guidance. Therefore, in writing news, journalists make careful efforts to provide fair and balanced news coverage. The intention is not to violate media policies but also it is to meet public expectations. 
From the perspective of audience, particularly in Greater Jakarta, the cyber media news coverage in these four areas is an interesting matter to be intensively further explored. The cyber media news coverage is a report presented by cyber media editors as a form of media that uses the internet and carries out journalistic activities and meets the requirements of the Press Law and Press Company Standards established by the Press Council. [4].

Has the cyber media in the four provinces carried out the appropriate news coverage of diversity? There are various reasons to determine the feasibility on the news coverage of diversity. It is seen not only from the viewpoint of media policy and the news coverage content of diversity, but also it relates to the existing social values in society and the sustainability of cyber media operations.

Based on the description at above, the research problems are: (1) cyber media policy in the news coverage of has the potential to hinder factual news coverage (2) the strategies of cyber media journalists in the news coverage of diversity so as not to violate the existing provisions and be accepted by public. Moreover, the research purpose is to describe the news coverage policy of cyber media and the news coverage of diversity in the regional level.

\section{METHODS}

This research on cyber media uses qualitative research methods with a phenomenological approach, to understand human behaviour and actions. The research purpose is to understand the cyber media policy in the news coverage of diversity as a sensitive matter. Moreover, it will find out the news coverage of diversity in regional cyber media directly. For this reason, data collection is carried out in accordance with the research topic. The qualitative research is a research procedure that produces descriptive data in the form of written and oral statements from people whose attitudes and behavior are being observed [5]. In the qualitative research, it is sometimes necessary to consciously calculate the frequency elements to avoid bias [6].

The research subjects are cyber media and informants determined purposively. Meanwhile, the research object is the cyber media policy and the cyber media news coverage strategy of diversity. To obtain data and information in accordance with the research topic, the research informants were determined using purposive sampling technique with a snowball pattern.

The purposive sampling technique with snowball will determine the informants or sources needed for the research. [7]. The first informant, a journalist, was observed deeply in relation to the research topic. Furthermore, the next informant was determined based on snowball system. From the purposive sampling and snowball models, the researchers obtained 9 (nine) informants who met the requirements. The informants are interested, accustomed and actively reading the cyber media news coverage of diversity in Indonesia. They consist of media journalists, civil servants, private employees, student activists, NGOs activist lecturers, public figures, legal consultants, private school teachers, and businessman. For the nine informants, face-to-face or online interviews were conducted. This is in line with the opinion that data collection can be carried out through observation, documentation, interviews, and available notes and documents. [8].

Data analysis was carried out in a kind of sorting various information to be grouped into certain descriptions. The data and information that are inconsistent with the research topic will be eliminated. Therefore, the data analysis results are not broad and not in line with the research topic that can describe the existing events as a whole.

\section{FINDINGS AND DISCUSSIONS}

\subsection{Cyber Media Policy News Coverage of Diversity}

Cyber media has news coverage guidelines on the basis of cyber media news coverage guidelines from the Press Council. However, in the implementation there are some differences. In the news coverage of sensitive issues concerning social, religious and ethnic values, each media has its own policies. Definitely these cannot be separated from the rules stated in Law Number 40 of 1998 concerning the Press [9].

Based on the research conducted in Surabaya and Pontianak, the trend of carefulness in the news coverage of diversity is very prominent. Almost all cyber media in the two cities at above have carried out it. Of the 37 cyber media in Surabaya and Pontianak particularly, it shows that almost all cyber media are careful. In fact, there is a small number of cyber media that state that they are very careful in the news coverage in cyber media [10].

Cyber media is a social control tool to prevent deviations from people's behaviour in the position of individuals and group members in the framework of diversity. This is in line with the opinion that online media position is as a medium that brings goodness and summarize all the aspirations of society [11].

The research data on the unconformity of intergroup relationship in the cyber media news coverage show that the role of government officials and public figures is needed in resolving conflicts. Of the 37 Cyber Media in West Java and East Java, 27 or around 73\% stated that the role of Government officials and community leaders was needed to resolve conflicts [12]. The data make it clear that cyber media news coverage policies are more comfortable if they prioritize the roles of the two parties. It is considered to represent the legality of power and society in general.

However, from the critical perspective, it is likely considered that the carefulness does not provide room for certain social groups. He emphasized that poor media content has a very large impact on vulnerable and weakened groups / communities. The uniqueness of being different in daily life of majority of the people tends to see them as abnormal, sick, sinful, or deviant as well. This 
condition is unfortunate because it will not establish a peaceful life together [13].

It cannot be ruled out that various pros and cons opinions always appear in the era of free speech. It develops in line with the state reform in Indonesia. Responding to the research results and opinions of human rights activists, Informant A, a journalist, stated:

We could understand if the news coverage in cyber media which was actually very careful, was not in line with the thoughts of some activists. However, it should ignore that cyber media also required sustainability in carrying out its news coverage function. Therefore, it did not establish counterproductive matters to cyber media including its news coverage. (The interview results, October 2020).
A similar opinion was expressed by Informant $\mathrm{F}$, a retired public figure who was a government employee:

The news coverage that we read on cyber media must be soothing because it is important for society to be peaceful. The cyber media policies have certainly considered various aspects of the pros and cons for public security. (Interview results for October 2020).

In general, the opinions of informants who generally understand the news coverage are different. On the one hand, despite it has similarities to prioritize the importance of good news coverage, it will fight the development of fake news. In detail, the brief opinion of the informants is as shown in the following table.

Table 1. Opinion of Informants on Cyber Media Policy

\begin{tabular}{|c|l|l|l|}
\hline No & Informants & \multicolumn{1}{|c|}{$\begin{array}{c}\text { General } \\
\text { Characteristics }\end{array}$} & \multicolumn{1}{|c|}{ Trend of Opinion } \\
\hline 1 & A/ Man & $\begin{array}{l}\text { Media Journalist living } \\
\text { in Greater Jakarta, } 45 \\
\text { years old }\end{array}$ & $\begin{array}{l}\text { It should be carefulness in the news coverage of } \\
\text { diversity }\end{array}$ \\
\hline 2 & B/ Man & $\begin{array}{l}\text { Civil Servant, 37 years } \\
\text { old }\end{array}$ & $\begin{array}{l}\text { Public is very sensitive to diversity issues } \\
\text { related to values and beliefs }\end{array}$ \\
\hline 3 & C/ Man & $\begin{array}{l}\text { Private Employee, 38 } \\
\text { years old }\end{array}$ & $\begin{array}{l}\text { It is understandable that carefulness relates to } \\
\text { the sustainability of cyber media operations }\end{array}$ \\
\hline 4 & D/ Man & $\begin{array}{l}\text { Activist Student, 25 } \\
\text { years old }\end{array}$ & $\begin{array}{l}\text { Carefulness is required but not to cover factual } \\
\text { information }\end{array}$ \\
\hline 5 & E/ Woman & $\begin{array}{l}\text { NGOs Activist, Lecturer, } \\
53 \text { years old }\end{array}$ & $\begin{array}{l}\text { In the diversity, an empathetic news coverage is } \\
\text { needed }\end{array}$ \\
\hline 6 & F/ Man & $\begin{array}{l}\text { Public Figure, 62 years } \\
\text { old }\end{array}$ & $\begin{array}{l}\text { The news coverage of diversity must be } \\
\text { soothing in order to fight fake news }\end{array}$ \\
\hline 7 & G/ Man & $\begin{array}{l}\text { Legal Consultant, 43 } \\
\text { years old }\end{array}$ & $\begin{array}{l}\text { The legal aspect definitely becomes the main } \\
\text { reference in the news coverage of diversity }\end{array}$ \\
\hline 8 & H/ Woman & $\begin{array}{l}\text { Private School Teacher, } \\
53 \text { years old }\end{array}$ & $\begin{array}{l}\text { In view of information from social media that } \\
\text { frequently heightens the situation, the cyber } \\
\text { media must provide enlightenment }\end{array}$ \\
\hline 9 & I/ Man & $\begin{array}{l}\text { Businessman, 33 years } \\
\text { old }\end{array}$ & \begin{tabular}{l} 
Carefulness is a principle of media security \\
\hline
\end{tabular} \\
\hline
\end{tabular}

Based on the above table, it can be seen that carefulness in the news coverage is required. However, it is reminded that in the era of communication freedom, despite people have different viewpoints and they can subjectively judge the news, the important thing is that the cyber media has followed the existing laws and regulations and the journalistic code of ethics.

It needs consistency from journalists and those who determine the news coverage policies in cyber media. It is undeniable that there are efforts from media owners who are actively in political activities and so, the news coverage focuses on benefits out of journalistic matters. In this condition, the media function as an entity that cares about disseminating information for public benefit is neglected. [14]. Moreover, it can be said that it is partisan media that dependently spreads messages to the public.

Cyber media in the news coverage of diversity has run properly according to the existing provisions. It refers Law
Number 40 of 1998 on the Press. Moreover, various guidelines must be followed depending on the affiliation of journalists, such as the Journalistic Code of Ethics from PWI (Indonesian Journalists Association), the Code of Ethics for the Independent Journalists Association (AJI) and the guidelines for cyber media news coverage from the Press Council. However, social values as the basic beliefs of society must become the reference. Particularly when it comes to ethnicity, religion, race, and ethnic groups that have the potential to trigger potential conflicts.

\subsection{Cyber Media News Coverage: Promoting Facts and Minimizing Rejection}

The regional cyber media news coverage encounters cyber media policy issues. In this matter, in addition to government laws and regulations, media owners and chief 
editors are also the gate keeper of the news coverage. Based on the review results of 100 cyber media news coverage in West Kalimantan Province and South Sulawesi Province, it is interesting to study. It includes the aspects of describing events / issues from the pros and cons side. Cyber media in the news coverage of diversity is sensitive to social and religious values, and it shows that $92 \%$ of news coverage content does not have pros and cons messages. There are only $8 \%$ that have the pros and cons in the news coverage of diversity.

Other news coverage content, which depicts events / issues from one side shows that cyber media avoid the news coverage from one side totalling $96 \%$. Other hand, there are only $4 \%$ that make the news coverage from one side. Particularly, the cyber media that tries to be neutral in the news coverage amounts to $86 \%$. Finally, there are $14 \%$ considered to have partiality.

The above results show that cyber media journalists have tried to follow the news coverage guidelines in relation to balance, independence, factual, and impartiality. As it is well known that diversity involves many issues. So it is not just the relationship between different groups. There is the news coverage of social groups that do not have the opportunity to appear in society or the marginalized communities. Ethnic, religious, racial and inter-group differences issues (SARA) are also a threat to diversity in society.

Therefore, taking sides can lead to problems or provoke rejection from society. If it occurs, it will not only jeopardize the cyber media, but also the pluralistic society. In fact, there are still a lot of cyber media news coverage that are not in line with the journalistic code of ethics as a reference for cyber media. [15]

Based on the above conditions, it can be known that the cyber media mostly tries to carry out the neutral news coverage. It does not take one side and not only prioritize one side in the news coverage. It means that it not only highlights one thing that is considered absolute truth, but also it suggests other aspects to maintain neutrality. [16]. However, there remain cyber media that take one side in the news coverage of social, economic, and political diversity. Concerning political issues, it is very possible if media owners or media crews have ties to any political parties. Despite the number is very small, it should be eliminated in the news coverage of diversity.

Responding to the news coverage in the regions, the opinion of the informants in the research varied. Briefly, the opinion of the informants relates events from the pros and cons, the news coverage of diversity from one side, and neutrality in the news coverage.

Table 2. Opinions on Content of Cyber Media News Coverage

\begin{tabular}{|c|c|c|c|}
\hline No & $\begin{array}{c}\text { News Coverage Content of } \\
\text { Diversity }\end{array}$ & Informants & $\begin{array}{c}\text { Essence of Opinion on Cyber } \\
\text { Media News Coverage }\end{array}$ \\
\hline 1 & $\begin{array}{c}\text { Events and issues of diversity are } \\
\text { presented in terms of pros and } \\
\text { cons that trigger conflicts of } \\
\text { interest. }\end{array}$ & A, B, F, and I & $\begin{array}{c}\text { Such a news coverage contains an } \\
\text { element of negligence from the cyber } \\
\text { media crew. So, it is not on purpose }\end{array}$ \\
\hline 2 & $\begin{array}{c}\text { News coverage of diversity from } \\
\text { one side. It is not balanced; all } \\
\text { parties get equal opportunities. }\end{array}$ & $\begin{array}{c}\text { B, C, F, H, } \\
\text { and I }\end{array}$ & $\begin{array}{c}\text { Inaccurate writing editor. News } \\
\text { coverage from one side usually } \\
\text { ignores vulnerable groups / } \\
\text { communities }\end{array}$ \\
\hline 3 & $\begin{array}{c}\text { The neutrality of news coverage } \\
\text { and refusing any party to interfere } \\
\text { and dominate the news coverage } \\
\text { content }\end{array}$ & $\begin{array}{c}\text { A, B, C, D, E, } \\
\text { F, H, I }\end{array}$ & $\begin{array}{c}\text { The principle of neutrality is in line } \\
\text { with the function of cyber media } \\
\text { which provides factual and impartial } \\
\text { news coverage }\end{array}$ \\
\hline
\end{tabular}

Based on the table, it can be shown in this case that actually cyber media relates to the performance of journalists whether they have implemented the existing laws and regulations or not. Moreover, it also takes into account the prevailing values in society. Finally, on sensitive issues such as differences in ethnicity, religion, race, and social groups (SARA), cyber media avoids the news coverage. [17]. A pluralistic Indonesian society must be nurtured through the carefulness of cyber media news coverage. [18].

Despite the news coverage content of diversity is presented in terms of the pros and cons, the informants have considered it as a mistake due to the journalists' carelessness and an unintentional act. In other words, cyber media does not intend to provoke the pros and cons, but it relates to the inappropriate skills of news coverage.
The news coverage also only contains the one unbalanced side. The essence of the informants' opinion confirms the editor's inaccuracy. It ignores weak social groups or communities that do not have the opportunity to appear in the media. Even so, there are those of the informants who have the opinion of practical reasons for the operational security of the cyber media in providing information to the public.

Moreover, what get high appreciation from the informants is neutrality in the news coverage. In the perspective of the informants, the principle of neutrality is in line with the function of cyber media which provides factual and impartial information. The neutrality of news coverage closely relates to the principle of media independence which produces news that is accurate, balanced and has no bad intentions. Independence means in accordance with the voice of conscience without any interference, coercion, 
and intervention from other parties, including the media owners. Meanwhile, balance tries to provide opportunities for all parties, including weak and marginalized communities in society.

With this condition, cyber media can position itself as main source of information for the public. The cyber media news coverage can also minimize the occurrence of fake news that potentially threaten the diversity of Indonesian society. Therefore, the existence of cyber media in the regions is still needed to maintain the diversity of Indonesian people and promote harmonious coexistence.

\section{CONCLUSIONS}

The regional cyber media news policy in the diversity coverage, bases on the real conditions it faces, i.e. the government laws and regulations, journalistic code of ethics and the consideration of social, economic, and political diversity in Indonesian society. It seems very careful for the sustainability of cyber media operations in carrying out its news coverage role for public.

Diversity news coverage in regional cyber media is in conformity with the principles of neutrality and independence. Neutrality is maintained so the regional cyber media becomes a public reference for obtaining correct and accurate information on reporting events in the field. Neutral news coverage of diversity can minimize fake news from unclear information sources.

\section{ACKNOWLEDGMENT}

The team of authors would like to thank Universitas Tarumanagara, Jakarta, for giving this paper the opportunity to be published.

\section{REFERENCES}

[1] Toural-Bran, C., Vizoso, Á., Pérez-Seijo,S., Rodríguez-C.M., Negreira-Rey, M.Z. (2020). Information visualization in the era of innovative journalism. New York: Routledge.

[2] AMSI. (2020). Dari 47 Ribu, Baru 2.700 Media Online Terverifikasi Dewan Pers. Available at: https://www.amsi.or.id/dari-47-ribu-baru-2-700-mediaonline-terverifikasi-dewan-pers/ (Accessed: 23 December 2020)

[3] Mansel, R. (2011). The handbook of global media and communication policy. West Sussex, Inggris Raya: Wiley-Blackwell
[4] Dewan Pers Indonesia. (2018). Media siber diatur dengan pedoman pemberitaan media siber tahun 2015 . Jakarta: Penerbit Dewan Pers Indonesia

[5] Creswell, J.W. \& Creswell, D. (2017). Research design: qualitative, quantitative, and mixed methods approaches. California, LA: Sage Publications

[6] Miles, M.B., Huberman. A.M. \& Saldana, J. (2019). Qualitative data analysis: a methods sourcebook. London: Sage Publications Inc.

[7] Sugiyono. (2016). Metode Penelitian Kuantitatif, Kualitatif, dan R \& D. Bandung: Penerbit Alfabeta

[8] Faisal, Sanapiah. (2017), Format-Format penelitian Sosial, Jakarta: Raja Grafindo Persada

[9] Undang - Undang Republik Indonesia Nomor 40 Tahun 1998 tentang Pers. Jakarta: Penerbit Kementerian Komunikasi dan Informasi

[10] Susanto, Junaidi \& Farid. (2020). Media siber, demokratisasi pemberitaan dan penyelesaian konflik. Dalam Heri Budianto \& Didik Suharyadi (ed). Dinamika Komunikasi Pembangunan Daerah. Yogyakarta: Penerbit MBridge Press.

[11] Ohorella, N.R. (2019). Strategi Media Online Lensatimur dalam Mengangkat Kearifan Lokal (Studi Kasus Pariwisata Indonesia Timur). Expose Jurnal Ilmu Komunikasi 2(1), 88-109

[12] Susanto, E.H., Junaidi, A., Rusdi, F (2020). The theme of diversity and conflict in siber indonesia media. Journal Talent Development and Excellence, Volume 12 (1), 5199-5207

[13] Nugroho, Y., Nugraha, LK., Laksmi, S., Amalia, M., Putri, DA., Amalia, D. (2012). Media dan Kelompok Rentan di Indonesia: Kisah dari Yang Terpinggirkan dan Tersisihkan. Riset kerjasama antara Centre for Innovation Policy and Governance and HIVOS Kantor Regional Asia. Tenggara, didanai oleh Ford Foundation. Jakarta: CIPG dan HIVOS.

[14] Pradita, E., Indirwan, I., \& Ihsanudin, M. (2018). Television media ownership as a political communication tool in the election. Law Research Review Quarterly, 4 (4), 1161-1178.

[15] Wiramarta. (2017). Studi kasus penerapan kode etik jurnalistik pada berita siber yang dibagikan melalui grup facebook "metro bali". Jurnal PRASI, 12 (1), 2031 
[16] Musfialdy. (2020). Independensi media: pro-kontra objektivitas dan netralitas pemberitaan media. Jurnal Riset Komunikasi, 2 (1), 21-28

[17] Madonna, M. (2019). Jurnalisme Provokasi Berbasis SARA: Studi Kasus Pemilihan Umum Presiden 2019. Jurnal Keamanan Nasional Volume, 5 (1), 65-81

[18] Susanto, E. H., Loisa, R \& Junaidi, A. (2020) Cyber media news coverage on diversity issues in Indonesia, Journal of Human Behavior in the Social Environment, 30 (4), 510-524 